\title{
PROFESI TENAGA BIMBINGAN DAN KONSELING YANG BERMARTABAT
}

\author{
Oleh : \\ I Made Olas Astawa \\ Dosen Fakultas Dharma Acarya IHDN Denpasar
}

\begin{abstract}
Consultancy and counselling services are helps provided to individuals in order that they become personalities with insight, view, skill that they are valuable in the societies. The Indonesian Government Regulation Nomor 20/ 2003 on the National Education System correctly states that councellors are educators, which means that those with the profession should produce work with high quality that they could develop students' potentialities to reach success, both formally and socially.

The works of a councellor depends on their qualification and competences that they gain from credible institutions. A councellor should be licensed and certified to indicate that he (she) has completed his (her) professional study and has been tested according to certain criteria given by a representative professional organisation or agency. This should be also supported with (1) dignity service, (2) tasked jobs, (3) healthy environment. These three can guarantee the maintenance of the professions.
\end{abstract}

Key Words : councelling, consultancy, dignity

\section{PENDAHULUAN}

Pelayanan bimbingan dan konseling membantu individu untuk menjadi insan yang berguna dalam kehidupan yang memiliki berbagai wawasan, pandangan, interprestasi, pilihan, penyesuaian, dan keterampilan yang tepat berkenaan dengan diri sendiri dan lingkungan. Bimbingan dan konseling merupakan proses yang menunjang pelaksana program pendidikan di sekolah, karena program-program bimbingan dan konseling meliputi aspek-aspek tugas perkembangan individu, khususnya menyangkut kawasan kematangan pendidikan dan karir, kematangan personal dan emosional, serta kematangan social. Hasil bimbingan dan konseling pada kawasan itu menunjang keberhasilan pendidikan umumnya.
Bimbingan dan konseling sebagai profesi yang sedang berkembang di negara Indonesia, harus dapat merebut kepercayaan publik (public trust) melalui peningkatan mutu unjuk kerja yang dilakukan oleh guru BK atau konselor yang profesional dalam bidang tugasnya. Masyarakat akan percaya bahwa layanan yang diperlukan itu hanya dapat diperoleh dari guru BK atau konselor yang memiliki kompetensi dan keahlian yang terandalkan. Kepercayaan publik inilah yang menjadi faktor kunci untuk mengokohkan identitas profesi. Kepercayaan ini dapat memberikan makna terhadap profesi dan memungkinkan anggota profesi akan menjalankan fungsinya di dalam cara-cara profesional. 


\section{PEMBAHASAN}

Undang-undang Nomor 20 Tahun 2003 tentang Sistem Pendidikan Nasional adalah sangat tepat menyebutkan bahwa konselor adalah pendidik, tentunya dengan makna agar para konselor itu melaksanakan kinerja profesional dalam kualitas yang tinggi bagi suksesnya pengembangan potensi peserta didik secara optimal pada segenap jalur, jenis dan jenjang pendidikan, baik dalam kelembagaan formal persekolahan maupun di masyarakat luas. Dalam hal ini secara khusus penulis ini menekankan, yaitu bahwa di satuan-satuan pendidikan tempat para guru dan guru BK atau konselor mengabdikan diri demi nusa dan bangsa, hendaknya terjadi kerja sama yang sangat baik antara kedua tenaga pendidik itu. Apabila kerja sama ini terjadi penulis yakin proses pembelajaran dan pembinaan peserta didik akan dapat berlangsung secara efektif untuk dicapainya hasil pendidikan yang terbaik. Mengingat sangat mulianya tujuan pendidikan kita dan beratnya beban pencapaian usaha dan misi pendidikan kita yang sangat luas dan beragam cakupannya. Kita memperhatikan pula kondisi nyata di lapangan, yang di samping tampak adanya kemajuan-kemajuan sangat berarti yang telah kita capai melalui programprogram pembangunan pendidikan, juga masih terjadi berbagai hal yang bisa dimaknai sebagai kurang berhasilnya upaya pendidikan kita. Kita bangga dengan prosentasi yang tinggi dalam angka kelulusan Ujian Nasional (UN), tetapi masih sering juga terdengar isu tentang praktik menyontek dalam ujian dan pembocoran soal ujian. Tawuran antar pelajar, antar mahasiswa, antar anggota masyarakat, gangguan keamanan dan perilaku menyimpang dan kurang terpuji, kejahatan, kekerasan pada umumnya, dan kekerasan dalam rumah tangga (KDRT), masih juga sering terjadi. Hampir setiap hari kita melihat berbagai tayangan dan pemberitaan di media massa yang isinya dapat membangkitkan hal-hal yang mengganggu kehidupan serta perkembangan mental-psikologis peserta didik.
Gangguan ini tentulah tidak boleh dibiarkan begitu saja, tetapi perlu ditanggulangi agar tidak menambah permasalahan yang lebih kompleks. Gangguan tersebut perlu dijernihkan sehingga peserta didik tidak justru terbawa arus oleh kondisi yang tidak kita harapkan itu. Penanggulangan tersebut sangat perlu kita upayakan agar tidak berpengaruh merugikan terhadap keberhasilan peserta didik dalam belajar dan pengembangan potensi mereka. Dalam hal ini kerja sama antara guru mata pelajaran dan guru BK atau konselor sangat diperlukan.

Kurikulum 2013 dirancang dengan tujuan untuk mempersiapkan insan Indonesia supaya memiliki kemampuan hidup sebagai pribadi dan warganegara yang produktif, kreatif, inovatif dan afektif serta mampu berkontribusi pada kehidupan bermasyarakat, berbangsa, bernegara dan peradaban dunia. Tahun 2020 sampai 2045 Indonesia dikaruniai potensi sumber daya manusia usia produktif. Investasi sumber daya manusia melalui pendidikan mempersiapkan sumber daya manusia generasi emas, yaitu generasi muda yang prduktif, kreatif, inovatif dan afektif.

Generasi muda adalah generasi masa sebagai sumber daya manusia yang perlu mendapat perhatian serius dalam era globalisasi saat ini karena generasi muda mempunyai peran yang sangat strategis dalam mensukseskan pembangunan nasional. Mutu generasi muda akan menjadi modal dasar bagi daya saing bangsa terutama diera masyarakat berpengetahuan. Peningkatan mutu generasi muda hanya dapat dilakukan melalui pendidikan yang bermutu. Mutu pendidikan secara kontekstual dan utuh, sesuai dengan kebutuhan peserta didik dan persoalan bangsa adalah sangat diperlukan pada saat idi dalam konteks pembangunan nasional.

Kaidah dasar yang dinyatakan secara eksplisit dalam kurikulum 2013 yang berkaitan langsung dengan pelayanan bimbinmgan dan konseling adalah kaidah peminatan. Peminatan 
dipahami sebagai upaya advokasi dan fasilitasi secara aktif mengembangkan potensi dirinya untuk memiliki kekuatan spiritual keagamaan, pengendalian diri, kepribadian, kecerdasan, akhlak mulia, serta keterampilan yang diperlukan dirinya, masyarakat, bangsa, dan negara (arahan pasal 1 angka 1 UU Nomor 20 Tahun 2003 Sisdiknas) sehingga mencapai perkembangan yang optimal. Perkembangan secara optimal bukan sebatas tercapainya prestasi sesuai dengan kapasitas intelektual dan minat yang dimilikinya, melainkan sebagai sebuah kondisi perkembangan yang memungkinkan peserta didik mampu mengambil pilihan dan keputusan secara sehat dan bertanggung jawab serta memiliki daya adaptasi tinggi terhadap dinamika kehidupan yang dihadapinya.

Kinerja konselor bermartabat sangat tergantung pada tingkat kualifikasi dan kompetensi yang dimilikinya melalui proses pendidikan dan pelatihan dari institusi yang kredebel. Seorang konselor harus mempunyai lisensi atau sertifikasi yang mengindikasikan bahwa pemiliknya berhasil menyelesaikan suatu pendidikan dan pelatihan dan sudah diuji berdasarkan kriteria belajar dan pengalaman yang direkomendasikan organisasi profesional yang refresentatif, dan lembaga/badan pelisensian yang tepat. Mc Cully (1962:682) menyatakan "sebuah profesi merupakan pekerjaan yang di dalamnya anggota-anggota suatu kelompok profesional memastikan kompetensi-kompetensi minimum siapapun yang ingin memasuki bidang kerja mereka, biasanya dilakukan dengan cara menetapkan dan menegakkan standar penyeleksian, pelatihan, dan pelisensian atau sertifikasi”.

Masyarakat Indonesia adalah masyarakat multikultural dan masyarakat modern. Masyarakat dan bangsa Indonesia memiliki kekayaan alam dan budaya luar biasa yang dapat dijadikan landasan bagi tumbuhnya system konseling di Indonesia. Di Indonesia terdapat berbagai macam kebudayaan yang berasal hampir dari seluruh suku bangsa. Dengan keanekaragaman ini kita dapat mewujudkan masyarakat multicultural, apabila warganya dapat hidup berdampingan, toleran dan saling menghargai. Nilai budaya tersebut bukan hanya sebuah wacana, tetapi harus menjadi patokan penilaian atau pedoman etika dan moral dalam bertindak yang benar dan pantas bagi orang Indonesia. Nilai tersebut harus dijadikan acuan bertindak, baik dalam bidang social, ekonomi, politik, maupun dalam tindakan individual.

Masyarakat Indonesia adalah masyarakat yang berkembang, yaitu berada dalam masa transisi dari masyarakat tradisional menuju ke masyarakat modern. Masyarakat Indonesia dipengaruhi oleh arus globalisasi dan perkembangan teknologi dan informasi, sehingga kemungkinan bertemunya orang-orang dari berbagai belahan dunia semakin besar pula. Pertemuan yang bukan hanya antar orangperorang semata, melainkan sesungguhnya juga antar budaya dengan berbagai keragamannya. Masyarakat Indonesia sebagai masyarakat multikultural yang kesadaran akan kehidupan sangat terbatas dan oleh sebab itu pula dunia kehidupannya bergerak dengan sangat lambat. Dengan pengaruh arus globalisasi masyarakat Indonesia menjadi masyarakat modern yang dapat menembus kehidupan tanpa batas, tanpa waktu, dan tanpa geografis. Namun, ketermelekan masyarakat modern atas kehidupan yang berubah cepat juga membawanya pada rasa keterasingan dan mungkin kegelisahan menghadapi perubahanperubahan yang begitu cepat. Keberadaan manusia modern ialah keberadaan di dalam suatu masyarakat yang penuh resiko, masyarakat yang berubah dengan cepat meminta manusia untuk mengambil sikap, mengadakan pilihan yang tepat untuk hidupnya atau dia hanyut bersama-sama dengan perubahan tersebut.

Pemahaman sikap seluk beluk budaya lokal dan sikap-sikap yang menyertai 
perbedaan antar-budaya, berkaitan dengan pergeseran antar-peradaban yang mempengaruhi pola-pola hubungan antar individu dan antar kelompok individu. Dalam hal ini, siapapun yang terlibat dalam kajian antar-budaya dituntut untuk memiliki perspektif global. Mungkin perspektif ini tidak langsung berkaitan dengan pemahaman konselor terhadap perilaku konseling, tetapi memberikan perspektif pada bagaimana seorang konselor dalam melakukan pelayanan konseling memposisikan dalam perkembangan global.

Peraturan Menteri Pendidikan Republik Indonesia Nomor 27 Tahun 2008 tentang Standar Kualifikasi dan Kompetensi konselor mempersyarat-kan bahwa kualifikasi konselor minimal sarjana pendidikan (S-1) Bidang Bimbingan dan Konseling dan tamatan Pendidikan Profesi Konselor (PPK), dan memiliki kompetensi paedagogik, kompetensi kepribadian, kompetensi sosial, dan kompetensi professional. Sebagai penyandang gelar profesi bimbingan dan konseling, konselor harus memiliki kompetensi : (1) memahami secara mendalam klien yang hendak dilayani; (2) menguasai landasan teoritik keilmuan pendidikan dan bimbingan dan konseling; (3) menyelenggarakan pelayanan bimbingan dan konseling terhadap klien; dan (4) mengembangkan pribadi dan profesionalitas diri secara berkelanjutan.

Konselor yang telah memenuhi standar kualifikasi akademik dan kompetensi, dalam mengelola kegiatan pelayanan konseling harus berfokus pada empat pilar kegiatan, yaitu (1) membuat perencanaan layanan dan kegiatan pendukung, mulai dari membuat program tahunan, semesteran, bulanan, mingguan, sampai dengan harian; (2) mengorganisasikan berbagai unsure dan sarana yang akan dilibatkan di dalam kegiatan; (3) melaksanakan konseling dengan berbagai jenis layanan dan kegiatan pendukung sesuai dengan masingmasing kegiatan yang telah direncanakan dan diorganisasikan; (4) mengontrol pelaksanaan pelayanan dalam bentuk penilaian hasil dan proses kegiatan serta mempertanggung jawabkan kepada pihak-pihak yang terkait.

Konselor dalam menjalankan profesi konseling harus benar-benar dipersiapkan dan dibina dengan sebaik-baiknya, dalam hal ini melalui pendidikan profesi dan sarana pembinaan lainnya, sehingga menjadi profesi yang benar-benar bermartabat. Konselor harus dapat mewujudkan dalam dirinya dalam bentuk spectrum suatu profesi konselor yang dapat digambarkan dalam bentuk trilogy sebagaimana terlihat pada gambar berikut ini.

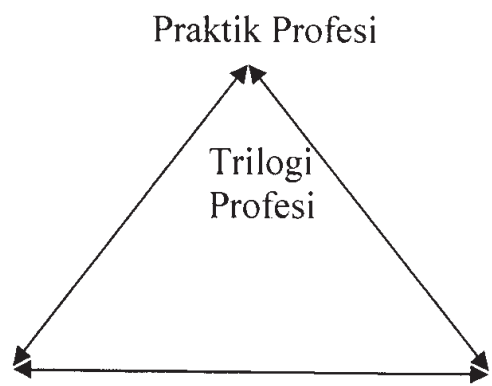

Dasar Keilmuan Substansi Profesi

Dalam suatu profesi konselor diidentifikasi tiga komponen yang sedcara langsung saling terkait, ketiganya harus ada, dan apabila salah satu atau lebih komponen itu tidak ada, maka profesi konselor akan kehilangan eksistensinya. Ketiga komponen trilogy profesi konselor adalah (1) dasar keilmuan, (2) substansi profesi, dan (3) dan praktik profesi.

\section{Komponen Dasar Keilmuan} menyiapkan calon konselor landasan dan arah tentang wawasan, pengetahuan, keterampilan, nilai dan sikap (WPKNS) berkenaan dengan profesi konseling. Konselor diwajibkan menguasai ilmu pendidikan sebagai dasar dari keseluruhan kinerja professional dalam bidang pelayanan konseling, karena konselor termasuk ke dalam kualifikasi pendidik. Hal ini sesuai dengan Undang-undang Nomor 20 Tahun 2003 tantang Sintem Pendidikan Nasional Pasal 1 butir 6 "Pendidik adalah tenaga kependidikan yang berkualifikasi senagai guru, dosen, KONSELOR, pamong belajar, widyaiswara, 
tutor, instruktur, fasilitator, dan sebutan lain yang sesuai dengan kekhususannya, serta berpartisipasi dalam menyelenggara- kan pendidikan. Dengan keilmuan inilah konselor akan menguasai dengan baik kaidah-kaidah keilmuan pendidikan sebagai dasar dalam memahami peserta didik (sebagai sasaran pelayanan konseling) dan memahami seluk beluk proses pembelajaran yang akan dijalani peserta didik (dalam hal ini klien) melalui modus pelayanan konseling. Dalam hal ini proses pelayanan konseling tidak lain adalah proses pembelajaran yang dijalani oleh sasaran layanan (klien) bersama konselornya. Dalam arti yang demikian pulalah, konselor sebagai pendidik diberi label juga sebagai agen pembelajaran.

Substansi Profesi Konseling memberikan modal tentang apa yang menjadi pokus dan obyek praktikspesifik profesi dengan bidang kajiannya, aspek kompetensi, sarana operasional dan manajemen kode etik serta landasan praktik operasional pekerjaan konseling. Di atas kaidah-kaidah ilmu pendidikan itu konselor membangun substansi profesi konseling yang meliputi obyek praktis spesifik profesi konseling, pendekatan dan teknologi pelayanan, pengelolaan dan evaluasi, serta kaidah-kaidah pendukung yang diambil dari bidang keilmuan lain. Semua substansi tersebut menjadi isi dan sekaligus fokus pelayanan konseling. Secara keseluruhan substansi tersebut sebagai modus pelayanan konseling. Obyek praktis spesifik yang menjadi fokus pelayanan konseling adalah kehidupan efektif sehari-hari (KES). Dalam hal ini, sasaran pelayanan konseling adalah kondisi KES yang dikehendaki untuk dikembangkan dan kondisi kehidupan efektif sehari-hari yang terganggung (KES-T). Dengan demikian, pelayanan konseling pada dasarnya adalah upaya pelayanan dalam pengembangan KES dan penanganan KES-T. Berkenaan dengan pendekatan dan teknologi, pengelolaan dan evaluasi pelayanan konseling, konselor wajib menguasai berbagai jenis layanan dan kegiatan pendukungnya dengan landasan teori, acuan praksis, standar prosedur operasional pelayanan konseling serta implementasinya dalam praktik konseling. Pendekatan dan teknologi, pengelolaan dan evaluasi pelayanan itu perlu didukung oleh kaidah-kaidah keilmuan dan teknologi seperti psikologi, sosiologi, antropologi, teknologi dan informasi komunikasi sebagai "alat" untuk lebih bertepatguna dan berdayaguna dalam pekayanan konseling.

Kita harus mengakui jika ikatan disipliner terkuat bagi profesi konselor adalah dengan bidang psikologi, namun juga harus mengakui kontribusi penting ilmu-ilmu lain bagi profesi konseling, sebagai contoh, sosiologi member kontribusi bagi pengertian tentang kelompokkelompok manusia dan pengaruhnya terhadap pranata dan perubahan sosial. Antropologi menyediakan bagi para konselor pemahaman tentang budaya-budaya manusia, yang pada gilirannya menyediakan rambu-rabu bagi cara bersikap dan memandang anggota-anggotanya. Biologi membantu konselor memahami organisme manusia dan keunikannya. Sedangkan profesi kesehatan membuat kita sadar pentingnya kesejahteraan hidup dan pencegahan dari penyakit, penyimpangan dan gangguan baik mental maupun fisik (Gibson \& Mitschel, 1995:29).

Praktik Pelayanan Konseling merupakan realisasi pelaksanaan pelayanan profesi konseling setelah kedua komponen profesi (dasar keilmuan dan substansi profesi) dikuasai. Praktik konseling terhadap sasaran pelayanan merupakan puncak dari keberadaan bidang konseling dalam setting pendidikan formal, pendidikan nonformal, keluarga, instansi negeri maupun swasta dunia usaha/industry, organisasi pemuda, organisasi kemasyarakatan, maupun praktik pribadi (privat). Mutu pelayanan konseling diukur dari penampilan (unjuk kerja, kinerja, performance) praktik pelayanan konseling oleh konselor terhadap sasaran layanan. Pada setting satuan pendidikan, 
misalnya, mutu kinerja konselor di sekolah/ madrasah dihitung dari penampilannya dalam praktik pelayanan konseling terhadap peserta didik yang menjadi tanggungjawabnya.

Memperhatikan ketiga komponen trilogi profesi tersebut, dapatlah dikatakan bahwa suatu "profesi konseling" tanpa dasar keilmuan yang tepat akan mewujudkan kegiatan "professional konseling" yang tanpa arah dan/atau bahkan malpraktik; tanpa substansi profesi, suatu "profesi konseling" itu akan kerdil, mandul dan dipertanyakan isi dan manfaatnya; dan tanpa praktik profesi, maka "profesi konseling" menjadi tidak terwujud, dipertanyakan eksisitensinya, dan tenaga "professional konselor" tidak berarti apa-apa bagi kemaslahatan kehidupan manusia. Ini berarti profesi konseling menjadi tidak bermartabat dan tidak dipercaya oleh masyarakat. Dalam kaitan itu semua, ketiga komponen Trilogi Profesi merupakan satu kesatuan tak terpisahkan, ketiganya merupakan kesatuan, dan dipelajari dalam program pendidikan Sarjana dan Pendidikan Profesi Konselor untuk mewujudkan kemartabatan dan public Trust profesi konseling di negara kita tercinta Indonesia.

Konselor dalam menyiapkan generasi emas Indonesia pada masyarakat multicultural dan modern dilakukan melalui pelayanan konseling yang bermartabat. Pelayanan konseling bermartabat akan dapat diwujudkan dalam kinerjanya didukung oleh kondsi:

1. Pelayanan bermanfaat, yaitu pelayanan professional yang diselenggarakan oleh konselor haruslah benar-benar bermanfaat bagi kemaslahatan kehidupan secara luas. Oleh karena itu, upaya pelayanan bimbingan dan konseling tidak boleh sia-sia atau terselenggara dengan cara-cara yang salah (malpraktik), melainkan terlaksana dengan manfaat yang setinggi-tingginya bagi sasaran pelayanan dan pihak-pihak lain yang terkait.

2. Pelaksana bermandat, yaitu pelayanan professional bimbingan dan konseling diselenggarakan oleh konselor yang bermandat. Pelayanan konseling harus dilakukan oleh tenaga yang benar-benar dipercaya untuk menghasilkan tindakan dan produkproduk pelayanan dalam mutu yang tinggi. Program pendidikan sarjana dan pendidikan profesi yang terpadu dan sinambung merupakan sarana dasar dan esensial untuk menyiapkan pelaksana bermandat. Lulusan pendidikan profesi konselor diharapkan menjadi tenaga professional handal yang layak memperoleh kualifikasi bermandat, baik dalam arti akademik, kompetensi,m maupun posisi pekerjaannya.

3 Pengakuan sehat, yaitu pelayanan professional bimbingan dan konseling diakui secara sehat oleh pemerintah dan masyarakat. Dengan kemanfaatan yang tinggi dan dilaksanakan oleh pelaksana yang bermandat, pemerintah dan masyarakat tidak ragu-ragu mengakui dan memanfaatkan pelayanan bimbingan dan konseling.

Ketiga hal tersebut dapat menjamin tumbtuh suburnya profesi konseling menjadi profesi yang bermartabat. Konseling sebagai suatu profesi yang sedang berkembang, para anggota profesi konseling harus berusaha memenuhi standar konselor agar konseling dapat merebut kepercayaan publik (public trust) melalui peningkatan kinerja konselor dalam pelayanan konseling bermartabat. Kekuatan eksistensi suatu profesi bergantung kepada public trust (Brigg \& Blocher, 1986). Masyarakat percaya bahwa layanan diperlukannya itu hanya dapat diperoleh dari konselor yang memiliki kompetensi dan keahlian 
yang terandalkan untuk memberikan pelayanan konseling.

Public trust akan mempengaruhi konsep profesi dan memungkinkan anggota profesi berfungsi dengan cara-cara professional. Public trust akan melanggengkan profesi konseling, karena dalam public trus terkandung keyakinan public bahwa profesi dan para anggotanya berada dalam kondisi: (a) memiliki kompetensi dan keahlian yang disiapkan melalui pendidikan dan latihan khusus dalam standar kecakapan yang tinggi; (b) memiliki perangkat ketentuan yang mengatur perilaku professional dan melindungi kesejahteraan publik; (c) anggota profesi dimotivasi untuk melayani pengguna dan pihak-pihak terkait dengan cara terbaik, dan memiliki komitmen untuk tidak mengutamakan kepentingan pribadi dan finansial.

Keefektifan seorang konselor dan sebuah konseling ditentukan oleh (a) kepribadian dan latar belakang konselor; (b) pendidikan formal yang didapat oleh konselor, dan (c) kemampuan konselor utnuk terlibat dalam kegiatan konseling professional seperti melanjutkan pendidikan, supervisi, advokasi, dan membangun portofoloio (Glading, 2009). Konselor dan proses konseling mempunyai efek yang dinamis terhadap orang lain; kalau tidak bermanfaat, kemungkinan besar justru memnerikan dampak yang tidak diinginkan (Carkhuff, 1969; Ellis, 1984; Mays \& Franks, 1980).

Keberadaan konselor dalam system pendidikan nasional dinyatakan sebagai salah satu kualifikasi pendidik, sejajar dengan kualifikasi guru, dosen, pamong belajar, konteks tugas dan tutor, widyaiswara, fasilitator, dan instruktur (UU Nomor 20 Tahun 2003 Pasal 1 ayat 6). Masing-masing kualifikasi pendidik, termasuk konselor memiliki keunikan konteks tugas dan ekspektasi kinerja. Konteks tugas konelor berada dalam kawasan pelayanan yang bertujuan mengembangkan potensi dan memandirikan konseling dalam pengambilan keputusan dan pilihan untuk mewujudkan kehidupan yang produktif, sejahtera, dan peduli kemaslahatan umum. Ekspektasi kinerja konselor dalam menyelenggarakan pelayanan ahli bimbingan dan konseling senantiasa digerakan oleh motif altruistic, sikap empatik, menghormati keragaman, serta mengutamakan kepentingan konseling, dengan selalu mencermati dampak jangka panjang dari pelayanan yang diberikan.

Kinerja konselor harus mengikuiti lima pedoman keprofesionalan (Belkin, 1975,1975: 171-172) sebagai berikut:

1. Kinselor harus mulai karirnya sejak hari pertama menampilkan diri sebagai konselor sekolah dengan program kerja yana jelas dan siap untuk melaksanakan program tersebut. Konselor yang sudah siap menjalankan tugas itu member kesempatan kepada seluruh personil sekolah dan siswa untuk mengetahui program-program yang hendak dijalankan.

2. Konselor sekolah harus selalu mempertahkan sikap professional tanpa mengganggu keharmonisan hubungan antar konselor dengan personil sekolah lainnya dan dengan sisa. Dalam hal ini konselor haris menonjolkan keprofesionalannya, tetapi tetap menghindarkan sikap elistis atau kesombongan/kengkuhan professional.

3. Tanggung jawab konselor untuk memahami perannya sebagai konselor professional dan menterjemahkan perannya kedalam kegiatan nyata.

4. Konselor sekolah agar dapat bekerja dengan efektif, harus memahami tanggung jawabnya kepada semua siswa, baik siswa yang gagal, yang menimbulkan gangguan, yang mengalami kesulitan belajar, maupun siswa-siswa yang mempunyai bakat istimewa (gifted), yang berpotensi rata- 
rata, yang pemalu dan menarik diri dari hadapan khalayak ramai, serta yang bersikap menarik perhatian atau mengambil muka pada konselor atau personil lainnya.

5. Konselor harus memahami dan mengembangkan kompetensi untuk membantu siswa-siswa yang mengalami maslaha dengan kadar yang cukup parah dan siswa yang mengalami gangguan emosional khusus, khususnya melalui programprogram kelompok, program kegiatan di luar sekolah dan pendidikan/ pembelajaran sekolah, dan bentuk pelayanan lainnya.

Dengan mengacu pada pedoman tersebut, profil konselor sekolah tampil dalam bentuk yang manarik dan menimbulkan harapan dan kepercayaan dari berbagai pihak. Tampilan ini tentunya mengangkat citra profesi. Oleh karena itu, hal ini penting dilakukan oleh setiap konselor sehingga dapat melakukan kinerja professional konseling secara berkualitas. Perwujudan kerja professional konselor ditunjang oleh jiwa profesionalisme yaitu sikap mental yang senantiasa mendorong dirinya untuk mewujudkan diri sebagai konselor professional. Pada dasarnya professionalisme itu merupakan motivasi intrinsik pada diri konselor sebagai pendorong untuk mengembangkan diri kearah perwujudan professional. Profesionalisme konselor mempunyai makna penting karena (1) profesionalisme merupakan cara untuk memperbaiki profesi konseling, (2) profesionalisme memberikan kemungkinan perbaikan dan pengembangan diri yang memungkinkan konselor dapat memberikan pelayanan sebaik mungkin dan memaksimalkan kompetensinya. Kualitas profesionalisme konselor ditunjukan oleh unjuk kerja dalam melaksanakan pelayanan konseling:

a. Keinginan untuk selalu menampilkan perilaku yang mendekati standar ideal; b. Meningkatkan dan memelihara citra profesi

c. Keinginan untuk senantiasa mengejar kesempatan pengembangan professional yang dapat meningkatkan dan memperbaiki kualitas pengetahuan dan keterampilan- nya;

d. Mengejar kualitas dan cita-cita dalam profesi; dan

e. Memiliki kebanggaan terhadap profesi.

Citra dan mutu kinerja konselor dapat ditegakkan bilamana dalam pelaksaan tugas profesionalnya konselor telah dapat mewujudkan hal-hal berikut.

1. Pelayanan konseling sebagai pelayanan sosial. Konselor dalam menangani masalah tidak disertai oleh penyikapan "negative antagonistic”, yaitu cenderung memandang masalah sebagai sesuatu yang tidak boleh ada, harus diberantas dengan segera, jika perlu dengan kekerasan. Melainkan disertai oleh penyikapan "sosial altruistik", yaitu memandang bahwa adanya masalah itu adalah wajar dan manusiawi serta penanganannya harus dilakukan secara lembut, teliti, hati-hati, serta penuh pertimbangan dan kesabaran. Jadi pelayanan yang diberikan oleh konselor secara tulus dengan mencurahkan segenap daya dan kemampuan yang ada demi keberhasilan dan kebahagiaan klien.

2. Pelayanan yang ditampilkan unik. Konselor harus mampu mengidentifikasi individu (klien) yang pemenuhannya perlu dilakukan melalui pelayanan konseling; dan dalam penanganannya menggunakan caracara yang berbeda dengan ahli lain seandainya ahli lain menangani juga masalah yang sama. Penangan 
konselopr terhadap individu yang mencuri misalnya, harus berbeda cara penanganannya dengan guru mata pelajaran, psikolog, dan sebagainya.

3. Penampilan layanan atas dasar kaidah-kaidah intelektual. Pelayanan konseling pada penyikapan altruistik lebih dapat diharapkan untuk menerapkan kaidah-kaidah intelektual disbanding dengan penanganan pada penyikapan negatif antagonistik.

4. Menjalankan kode etik professional. Kode etik sangat penting bagi mutu layanan dan penerimaan klien serta masyarakat atas layanan tersebut. Dengan kode etik yang mantap klien dan masyarakat akan meningkatkan persepsi mereka terhadap pelayanan konseling dan akan mempercayakan dengan sepenuh hati penanganan masalah mereka kepada konselor. Sebaliknya bila pelaksanaan kode etik kedodoran, konselor dijauhi oleh (calon) klien dan masyarakat akan mengecam serta melontarkan predikat yang pasti merugikan konselor dengan profesi konseling.

\section{KESIMPULAN}

Kinerja professional merupakan tuntutan bagi konselor apabila ingin disebut sebagai tenaga professional. Konselor professional ditandai dengan rangkaian kata: ApaBagaimana-Mengapa. Konselor harus tahu (paham, mengerti) APA tugas pekerjaanya? Tahu (paham) BAGAIMANA menjalankan tugas pekerjaanya? Tahu (paham) MENGAPA ia melakukan suatu tugas itu? Jika konselor hanya tahu apa tugas yang dikerjakannya dan tahu betul bagaimana melakukan tugas pekerjaan itu, tetapi konselor tidak tahu mengapa melakukan tugas itu seperti yang dilakukannya, maka; sejatinya dia bukan konselor professional; konselor dikatakan, ibaratnya ia turun derajat menjadi seorang "tukang", atau "pesuruh", bukan atau belum seorang konselor professional dalam arti yang sebenarnya. Ia bukan seorang pengambil keputusan.

Konselor penting untuk: Menguasai pengertian dan hakikat profesi; Memiliki kesadaran profesi. Mengapa? Karena pengertian hakikat profesi dan kesadaran profesi akan menentukan bagaimana kita dalam menjalankan tugas profesi pendidikan. Karena merupakan landasan dalam usaha besar mengangkat derajat dan martabat profesi pendidikan. Kinerja professional konselor pada dasarnya merupakan perwujudan professional yang secara sadar dan terarah untuk melaksanakan tugas: kegiatan konseling bagi konselor. Dalam rangka untuk mewujudkan kinerjanya sebagai konselor yang professional, bermutu, dan bermartabat, maka konselor harus meningkatkan kinerja profesionalnya dan Profesionalitasnya melalui profesionalisasi diri.

Profesionalisasi menunjuk kepada proses peningkatan kualifikasi dan kompetensi konselor sebagai anggota profesi dalam mencapai criteria standard an dalam kinerjanya menjalankan tugas utama profesi. profesionalisasi merupakan proses yang berlangsung: sepanjang hayat, dan tanpa henti. Profesionalisasi pada dasarnya merupakan serangkaian proses pengembangan keprofesionalan berkelanjutan, baik dilakukan melalui : pendidikan/latihan prajabatan (pre-service training); maupun pendidikan/layihan dalam jabatan (in- service training). Kinerja konselor dalam pelayanan konseling terhadap individuindividu sebagai sasaran layanan dalam masyarakat multicultural dan masyarakat modern diharpkan dapat mewujudkan masyarakat Indonesia yang produkti, inovativ, kreatif, dan afektif, serta meningkatkan harkat dan martabat bangsa. Keberhasilan dalam pelayanan konseling yang bermartabat akan memberikan kontribusi besar pada pencapaian tujuan pembangunan pendidikan nasional secara keseluruhan. 


\section{DAFTAR PUSTAKA}

Direktorat Jendral Pendidikan Tinggi (2004). Dasar Standarisasi Profesi Konseling

Gladding, S.T. (1988). Counseling : A Counseling Profesion. Colombus, Ohio: Merril Publishing Company.

Gladding, S.T. (2012 : terjemahan). Konseling : Profesi menyeluruh. Jakarta : PT Indeks.

Marjohan dkk (2012) Biografi Keilmuan Prayitno dalam sebuah Ranah Konseling dan Pendidikan Padang : UNP.

Permendiknas Nomor 27 Tahun 2008 tentang Standar Kualifikasi Akademik dan Kompetensi konselor.

Prayitno (1987). Profesionalisasi Konseling dan Pendidikan Konselor. Jakarta : P2LPTK Depdikbud.
Prayitno (1990). Konselor Masa Depan dalam Tantangan dan Harapan. Pidato Pengukuhan sebagai Guru Besar Tetap dalam Bidang Bimbingan dan Konseling pada FIP IKIP Padang, di Padang, 26 Desember 1990.

Prayitno (1997). Dasar Teori dan Praksis Pendidikan. Jakarta : Gramedia/ Grasindo

Prayito (2005) Kerangka Konseling Eklektik : Konseling Pancawaskita. Padang : Program PPK UNP/

Prayitno (2009 b). Wawasan Profesional Konseling. Padang : UNP.

Prayitno (2012 b). Spektrum Pelayanan Konseling. Padang : UNP

Undang-Undang Nomor 20 Tahun 2003 tentang Sistem Pendidikan Nasional. 